\title{
Pengaruh Kecerdasan Emosional, Kompetensi Kerja, dan Komitmen Organisasi terhadap Kepuasan Kerja, Serta Implikasinya pada Kinerja Perawat Puskesmas
}

\author{
(Studi Empiris pada Perawat Puskesmas di DKI Jakarta)
}

\author{
Rosidi Roslan \\ Dosen Departemen Kesehatan Masyarakat, Sekolah Tinggi Ilmu Kesehatan Indonesia Maju \\ J. Harapan No.50 Lenteng Agung, Jakarta Selatan \\ Email : rosidiroslan71@gmail.com
}

\begin{abstract}
Abstrak
Penelitian ini bertujuan untuk mengetahui dan menganalisis pengaruh kecerdasan emosional, kompetensi kerja dan komitmen organisasi terhadap kinerja perawat Puskesmas (Studi Empiris pada Perawat Puskesmas di DKI Jakarta) melalui kepuasan kerja baik secara parsial maupun secara bersama-sama. Populasi penelitian adalah seluruh perawat Puskesmas di DKI Jakarta. Metode penelitian yang digunakan dalam penelitian ini adalah analisis deskriptif dan verifikatif, dengan menggunakan ukuran sampel sebesar 220 responden, serta metode analisis data yang digunakan adalah SEM (Structural Equation Modelling). Berdasarkan hasil penelitian, didapatkan temuan bahwa kecerdasan emosional, kompetensi kerja dan komitmen organisasi baik secara parsial maupun secara bersama-sama, berpengaruh positif dan signifikan terhadap kepuasan kerja dengan koefisien determinasi sebesar 0.56. Kecerdasan emosional merupakan variabel yang paling dominan yang mempengaruhi kepuasan kerja perawat Puskesmas di DKI jakarta. Selanjutnya kecerdasan emosional, kompetensi kerja, komitmen organisasi dan kepuasan kerja, secara parsial maupun bersama-sama, berpengaruh secara positif dan signifikan terhadap kinerja perawat Puskesmas di DKI Jakarta, dengan koefisien determinasi sebesar 0.84 . Komitmen organisasi merupakan variabel yang paling dominan yang mempengaruhi kinerja perawat Puskesmas di DKI Jakarta. Kepuasan kerja berperan sebagai parsial mediasi dalam peningkatan kinerja perawat, karena kompetensi kerja dan komitmen organisasi memiliki pengaruh langsung yang lebih besar terhadap peningkatan kinerja perawat Puskesmas di DKI Jakarta.
\end{abstract}

Kata kunci : Kecerdasan emosional, Kompetensi kerja, Komitmen organisasi, Kepuasan kerja, Kinerja Perawat

\begin{abstract}
This study aims to determine and analyze the influence of emotional intelligence, work competency and organizational commitment on the performance of health center nurses (Empirical Study on Health Center Nurses in DKI Jakarta) through job satisfaction both partially and jointly. The study population was all Puskesmas nurses in DKI Jakarta. The research method used in this study is descriptive and verification analysis, using a sample size of 220 respondents, and the data analysis method used is SEM (Structural Equation Modeling). Based on the results of the study, it was found that emotional intelligence, work competence and organizational commitment both partially and jointly had a positive and significant effect on job satisfaction with a determination coefficient of 0.56. Emotional intelligence is the most dominant variable that influences the job satisfaction of the Puskesmas nurses in DKI Jakarta. Furthermore, emotional intelligence, work competence, organizational commitment and job satisfaction, partially or jointly, have a positive and significant effect on the performance of the Puskesmas nurses in DKI Jakarta, with a coefficient of determination of 0.84. Organizational commitment is the most dominant variable that influences the performance of Puskesmas nurses in DKI Jakarta. Job satisfaction serves as a partial mediation in improving nurse performance, because work competence and organizational commitment have a greater direct influence on improving the performance of nurses at the Puskesmas in DKI Jakarta.
\end{abstract}

Keywords : Emotional intelligence, work competency, organizational commitment, job satisfaction, nurse performance 


\section{Pendahuluan}

Perawat peranan penting dalam meningkatkan derajat kesehatan masyarakat. Upaya yang dilakukan perawat ditujukan untuk meningkatkan kesadaran, kemauan, dan kemampuan masyarakat untuk hidup sehat dan aktif berperan serta dalam upaya kesehatan. Salah satu unit pelaksana pelayanan kesehatan yang langsung berhadapan dengan masyarakat adalah pusat kesehatan masyarakat (Puskesmas). Pelayanan kesehatan diberikan kepada seluruh lapisan masyarakat dengan memfokuskan pada promotif dan preventif tanpa mengabaikan kuratif dan rehabilitatif. Upaya pelayanan kesehatan dasar kepada masyarakat diselenggarakan melalui upaya kesehatan wajib dan upaya kesehatan pengembangan di Puskesmas. Upaya kesehatan tersebut dapat diintegrasikan dalam upaya perawatan kesehatan masyarakat (perkesmas). Pelaksanaan Perkesmas bertujuan untuk meningkatkan kemandirian masyarakat dalam mengatasi masalah kesehatan yang dihadapi, sehingga tercapai derajat kesehatan yang optimal. ${ }^{1,2}$

Dinas Kesehatan Provinsi DKI Jakarta mulai menggalakkan kembali kegiatan perkesmas sejak tahun 2008. Kegiatan perkesmas didukung dengan pelatihan yang telah dilaksanakan empat kali antara bulan Juni 2008 hingga Maret 2010 dengan jumlah peserta sebanyak 38 perawat Puskesmas se-DKI Jakarta. Fokus kegiatan perkesmas di DKI Jakarta yaitu individu atau keluarga tidak mampu dengan resiko tinggi seperti bayi, balita, ibu hamil, ibu menyusui, usia lanjut, dan penyakit infeksi yang tingkat penularannya cepat, seperti TBC, kusta, HIV/AIDS, dan lain-lain. ${ }^{3}$

Kegiatan perkesmas yang dilakukan mencakup asuhan keperawatan pasien yang kontak dengan Puskesmas, kunjungan rumah, dan kunjungan ke kelompok prioritas terencana. Kunjungan ke kelompok prioritas terencana (posyandu balita dan lansia) yang biasa dilakukan lebih berfokus pada pengobatan dan imunisasi sehingga dirasakan belum optimal padahal perawat dapat melakukan deteksi dini (sasaran prioritas) untuk menanggulangi permasalahan kesehatan pada individu tertentu. ${ }^{3}$

Namun belum ada peningkatan yang signifikan pada angka kunjungan masyarakat ke Puskesmas di seluruh wilayah Provinsi DKI Jakarta. Bahwa pada rentang tahun 2011 ke tahun 2012 terjadi peningkatan jumlah kunjungan Puskesmas yaitu dari 7.853,42 menjadi 8.082,54. Namun masuk ke tahun 2013 dan 2014 terjadi penurunan drastis jumlah kunjungan ke Puskesmas. Hal ini menunjukkan kurangnya minat masyarakat dalam memanfaatkan Puskesmas, terlebih lagi jika dibandingkan dengan proyeksi penduduk DKI Jakarta tahun 2015 menurut BPS Provinsi DKI Jakarta sejumlah 10,15 juta jiwa. Total kunjungan rawat jalan Puskesmas di seluruh Provinsi DKI Jakarta pada tahun yang sama sebanyak 6.308.629. Data lima tahun terakhir ini menunjukkan tren jumlah kunjungan Puskesmas (rawat jalan) di Provinsi DKI Jakarta cenderung menurun. ${ }^{4}$

Kegiatan perkesmas yang digalakkan pun belum membawa dampak kesehatan di masyarakat. Pada 2009 jumlah penyakit yang tertinggi masih bersumber dari lingkungan seperti ISPA dan penyakit kulit, bahkan terjadi kejadian luar biasa Demam Berdarah Dengue (KLB DBD) yang kasusnya meningkat hingga 1000 persen. Masalah kesehatan lain yang juga menjadi masalah adalah penyakit karena perilaku yang salah seperti hipertensi dan penyakit pulpa dan jaringan periapikal. Masalah kesehatan tersebut menjadi tanggung jawab bersama antara pemerintah dan masyarakat dalam menanggulangi nya. Salah satu upaya yang dilakukan adalah melalui kegiatan perkesmas yang pelaksanaannya terintegrasi dalam upaya kesehatan wajib dan upaya kesehatan pengembangan di Puskesmas. ${ }^{4}$

Untuk dapat mengetahui kinerja Puskesmas secara keseluruhan, maka perlu 
dilakukan pemantauan terhadap hasil kinerja Puskesmas yang bersangkutan. Hasil kinerja perkesmas tersebut dapat dilihat melalui penyajian Pemantauan Wilayah Setempat (PWS) berupa tabel maupun grafik. PWS berisikan penyajian jenis dan jumlah target sasaran pelayanan, penyampaian hasil cakupan atau capaian pelayanan, dan penampilan hasil pengolahan data pelayanan. Penyajian kinerja perkesmas ini belum dilaksanakan oleh semua Puskesmas.

Salah satu kegiatan keperawatan pada Puskesmas-Puskesmas adalah pemberian tablet Fe untuk ibu hamil dan penanganan komplikasi di Puskesmas. Kegiatan tersebut menggambarkan kinerja perawat yang ada di Puskesmas-Puskesmas Provinsi DKI Jakarta.

Berdasarkan data kinerja perawat di Puskesmas-Puskesmas Provinsi DKI Jakarta Tahun 2012 - 2015 menunjukkan bahwa target pemberian $\mathrm{Fe}$ adalah $95 \%$ sedangkan target komplikasi adalah $71,50 \%$. Adapun realisasi pemberian tablet $\mathrm{Fe}$ yang dicapai pada tahun 2012 yaitu $92,70 \%$, tahun 2013 yaitu $79,60 \%$, tahun 2014 yaitu 94,80\% serta tahun 2015 yaitu $97,12 \%$. Sedangkan realisasi komplikasi pada tahun 2012 yaitu 63,85\%, tahun 2013 yaitu $65,43 \%$, tahun 2014 yaitu 71,09 serta tahun 2015 70,15\%. Apabila dilihat dari rata-rata baik pemberian $\mathrm{Fe}$ maupun Komplikasi masih berada di bawah target yaitu $91,06 \%$ dan $67,63 \%$. Hal ini mengindikasikan bahwa fenomena kinerja perawat secara rata-rata menurut target dan realisasinya selama 4 tahun $(2012-2015)$ masih rendah atau belum mencapai yang sudah ditargetkan oleh Dinas Kesehatan Provinsi DKI Jakarta. Berdasarkan studi awal yang dilakukan peneliti pada tanggal 27 April 2010 terhadap 5 Puskesmas di DKI Jakarta diketahui bahwa Puskesmas belum melakukan penyajian PWS khususnya untuk kegiatan perkesmas. Selain itu sumber data menunjukkan bahwa kegiatan perkesmas khususnya pada kunjungan rumah baru dilaporkan oleh 13
Puskesmas dari 23 Puskesmas yang ada di DKI Jakarta. ${ }^{4}$

Di samping data di atas peneliti juga melakukan survey awal terhadap 50 orang kinerja perawat Puskesmas yang hasilnya bahwa kinerja perawat pada PuskesmasPuskesmas di Provinsi DKI Jakarta dimana kuantitas hasil kerja dan kreativitas dalam bekerja masih di bawah standar sedangkan kualitas kerja dan inisiatif dalam bekerja sudah melebihi standar kerja.

Dari beberapa data yang di dapat melalui laporan resmi dari referensi yang ada maupun dari survey awal lapangan, maka timbul dugaan bahwa kurang maksimalnya kinerja Puskesmas di Provinsi DKI Jakarta ini diantaranya diakibatkan oleh kurangnya kepuasan kerja, kecerdasan emosional, kompetensi kerja, dan komitmen organisasi yang masih belum maksimal dari para Perawat Puskesmas di Provinsi DKI Jakarta..

\section{Metode}

Metode penelitian yang digunakan adalah metode survey, yang dilakukan dengan menggunakan angket sebagai alat penelitian. Unit analisis dalam penelitian ini adalah individu, yaitu Perawat Puskesmas di Provinsi DKI Jakarta. Analisis dilakukan dengan membandingkan antara kenyataan dan teori-teori yang didapat dari literatur.

Instrumen yang berhasil disusun perlu diujicobakan mengikuti prosedur: (a) menentukan responden uji coba; (b) pelaksanaan uji coba; dan (c) analisis instrumen.

Pengujian validitas untuk melihat sejauh mana instrumen dapat mengukur apa yang ingin diukur dan dilihat pada validitas dan reliabilitas instrumen.

Populasi penelitian yaitu seluruh perawat yang ada di DKI Jakarta sebesar 1024 perawat yang terbagi ke dalam 5 wilayah Jakarta yaitu wilayah Jakarta Barat, Jakarta Timur, Jakarta Utara, Jakarta Pusat, Jakarta Selatan serta termasuk dengan wilayah Kepulauan Seribu. Tabel 1.2 berikut ini adalah deskripsi jumlah 
perawat di masing-masing wilayah tersebut:

Tabel 1. Populasi Penelitian

\begin{tabular}{llc} 
No & \multicolumn{1}{c}{ Wilayah } & $\begin{array}{c}\text { Populasi } \\
\text { Penelitian }\end{array}$ \\
\hline 1. & Jakarta Barat & 226 \\
\hline 2. & Jakarta Timur & 265 \\
\hline 3. & Jakarta Utara & 148 \\
\hline 4. & Jakarta Pusat & 126 \\
\hline 5. & Jakarta Selatan & 235 \\
\hline 6. & Kepulauan Seribu & 24 \\
\hline Total & $\mathbf{1 0 2 4}$ \\
\hline \multicolumn{2}{l}{ Sumber: Dinas Kesehatan DKI Jakarta (2015) }
\end{tabular}

Jumlah sampel penelitian sebanyak

220 responden, dengan metode pengambilan sampel dilakukan dengan teknik proportional random sampling (sampel acak proporsional). Tabel 1.3 berikut ini adalah proporsi sampel penelitian mengacu pada jumlah populasi:

Tabel 2. Populasi dan Sampel Penelitian

\begin{tabular}{|c|c|c|c|}
\hline No & Wilayah & $\begin{array}{l}\text { Populasi } \\
\text { Penelitian }\end{array}$ & $\begin{array}{l}\text { Sampel } \\
\text { Penelit } \\
\text { ian }\end{array}$ \\
\hline 1. & Jakarta Barat & 226 & 49 \\
\hline 2. & Jakarta Timur & 265 & 57 \\
\hline 3. & Jakarta Utara & 148 & 32 \\
\hline 4. & Jakarta Pusat & 126 & 27 \\
\hline 5. & Jakarta Selatan & 235 & 50 \\
\hline 6. & Kepulauan Seribu & 24 & 5 \\
\hline Tot & & 1024 & 220 \\
\hline
\end{tabular}

Tipe validitas yang digunakan adalah validitas konstruk (validity construct) yang menentukan validitas dengan cara mengkorelasikan antar skor yang diperoleh masing-masing item yang dapat berupa pertanyaan maupun pertanyaan dengan skor totalnya.

Rumus korelasi yang digunakan dalam penelitian ini adalah KMO (KaiserMeyer-Olkin) mengukur kecukupan sampling (sampling adequacy). Indeks ini membandingkan besarnya koefisien korelasi terobservasi dengan besarnya koefisien korelasi parsial. Nilai KMO yang kecil menunjukkan bahwa korelasi antarpasangan variabel tidak bisa diterangkan oleh variabel lainnya dan analisis faktor mungkin tidak tepat. Bila nilai Kaiser Meyer Olkin (KMO) lebih dari 0,50 maka menandakan bahwa instrumen valid karena sudah memenuhi batas standar nilai KMO yaitu $0,50(>0,50)$ dan proses analisis dapat dilanjutkan. Signifikansi Bartlett's test $0,00(<0,05)$ mengindikasikan ada korelasi yang cukup antara variabel untuk dapat diproses. Proses selanjutnya adalah melihat tabel Anti-image Matrics, untuk menentukan variabel mana saja yang layak digunakan dalam analisis lanjutan. Jika nilai MSA lebih dari $0,50 \quad(>0,50)$ menunjukkan variabel layak untuk dianalisis.

Uji Reliabilitas ini dilakukan untuk mengetahui tingkat konsistensi hasil pengukuran jika dilakukan pengukuran ulang terhadap gejala dan alat ukur yang sama. Untuk melakukan uji reliabilitas, Peneliti menggunakan rumus Alpha Cronbach. Jika nilai reliabilitas alpha lebih besar dari 0,7 maka instrumen dapat dinyatakan reliabel.

Pendekatan dalam pemodelan serta teknik solusi yang digunakan sebagai alat analisis (tool analysis) di dalam penelitian disertasi ini adalah dengan menggunakan Structural Equation Modelling (SEM). Gambar 1 berikut ini menjelaskan hubungan antara lima variabel yaitu, tiga variabel laten eksogen (KE, KOM, KO) dan dua variabel laten endogen (KK, KP), dan juga mengambarkan model hubungan antar variabel secara skematik.

\section{Hasil dan Pembahasan \\ Pengujian Data Model SEM (Lisrel)}

Hasil analisis untuk pengujian model merupakan output Lisrel. Berdasarkan hasil analisis data tersebut dan untuk memenuhi syarat data yang digunakan sekurang-kurangnya mempunyai tingkat pengukuran interval.

Analisis pengujian model dengan menggunakan metode SEM diperlukan, bertujuan untuk mengetahui apakah model yang diperoleh telah memenuhi ukuran 
ketepatan model (Goodness of fit measures). Model hasil data estimasi dapat dikatakan baik bila memenuhi persyaratan model fit, maka harus melalui beberapa kriteria pengujian.

\section{Pengujian Hipotesis Struktur Persamaan -1 Hasil Penelitian}

Berdasarkan hasil analisis data kecerdasan emosional, kompetensi kerja dan komitmen organisasi terhadap kepuasan kerja disajikan pada gambar 1 berikut:

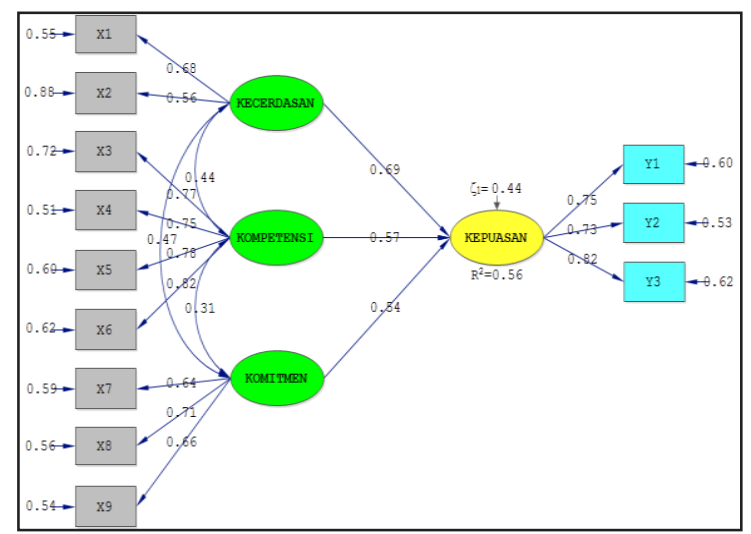

Gambar 1. Diagram Jalur Model Persamaan Struktural-1 Hasil Penelitian

Sumber: Output hasil pengolahan lisrel

Berdasarkan pada Gambar 1. tersebut kausalitas variabel kecerdasan emosional, kompetensi kerja dan komitmen organisasi terhadap kepuasan kerja dapat ditulis persamaan:

Kepuasan $=0.69 *$ Kecerdasan + $0.57 *$ Kompetensi $+0.54 *$ Komitmen + Errorvar. $=0.44, \mathrm{R}^{2}=0.56$

\section{Pengujian Hipotesis Struktur Persamaan -2 Hasil Penelitian}

Berdasarkan hasil analisis data pengaruh kecerdasan emosional, kompetensi kerja dan komitmen organisasi serta kepuasan kerja secara parsial dan simultan terhadap kinerja perawat dapat dilihat pada Gambar 2 berikut ini :

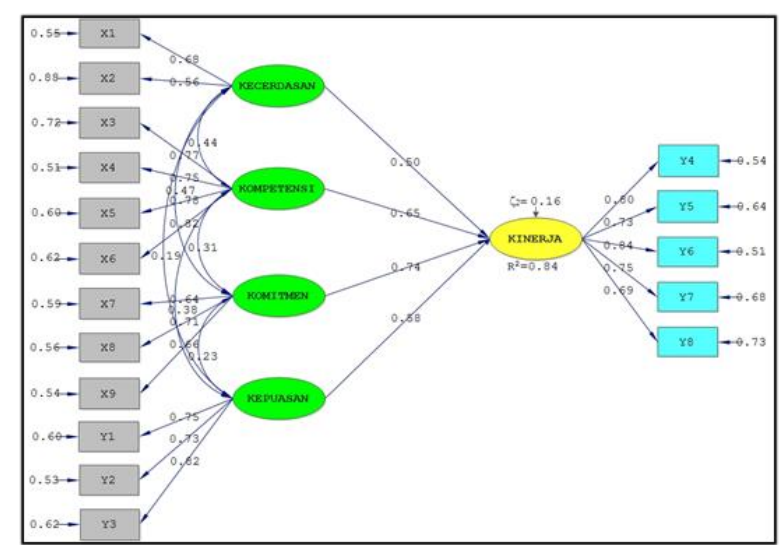

Gambar 2. Diagram Jalur Model Persamaan Struktural-2 Hasil Penelitian

Sumber: Output hasil pengolahan Lisrel

Berdasarkan Gambar 1.5 di atas hasil uji hipotesis-2, kausalitas variabel kecerdasan emosional, kompetensi kerja dan komitmen organisasi serta kepuasan kerja terhadap kinerja perawat merupakan bentuk persamaan dari:

Kinerja $=0.50 *$ Kecerdasan + $0.65 *$ Kompetensi $+0.74 *$ Komitmen + $0.58 *$ Kepuasan + Errorvar. $=0.16, \mathrm{R}^{2}=$ 0.84 .

\section{Analisis Pengaruh Langsung, Moderasi dan Total}

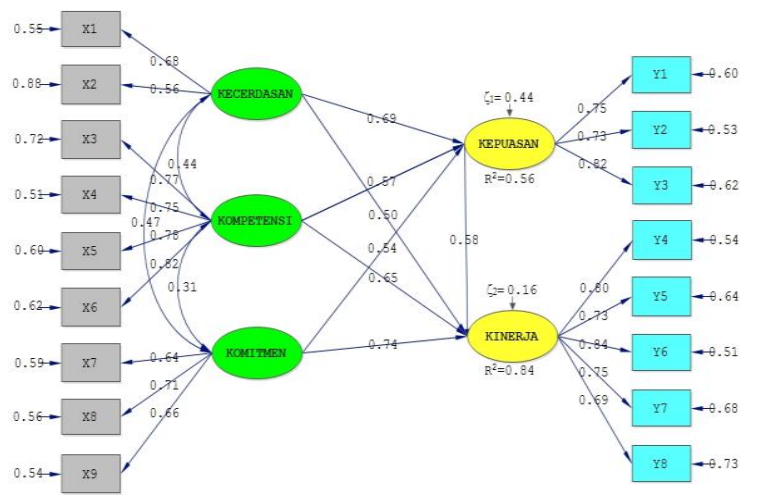

Gambar 3. Diagram Jalur Keseluruhan Penelitian Sumber: Output hasil pengolahan Lisrel

Model penelitian ini melibatkan variabel mediasi yaitu kepuasan kerja. Pengaruh langsung dihitung dari nilai koefisien jalur berdasarkan uji parsial, sedangkan uji mediasi dihitung 
berdasarkan perkalian antara koefisien jalur variabel eksogen terhadap kepuasan kerja dan koefisien jalur kepuasan kerja terhadap kinerja perawat. Secara keseluruhan hasil data penelitian dapat dilihat pada gambar 3 .

Untuk meyakinkan bahwa variabelvariabel berpengaruh signifikan, maka harus diuji secara parsial dengan t-value berdasarkan hasil analisis data menggunakan program lisrel yang hasilnya nampak pada gambar 4 berikut ini :

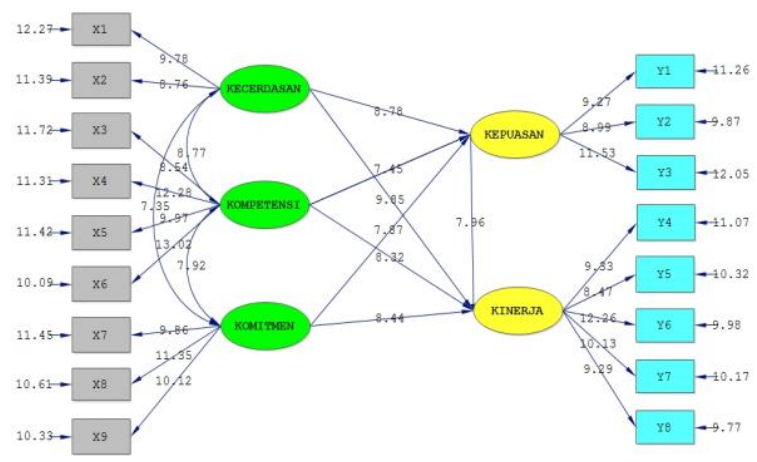

Gambar 4. Diagram Jalur t-value Penelitian Sumber: Output hasil pengolahan Lisrel
Untuk mengetahui besarnya pengaruh langsung dan tidak langsung kecerdasan emosional, kompetensi kerja, komitmen organisasi dan kepuasan kerja serta kinerja perawat, dapat dilihat pada tabel 1.

Berdasarkan tabel 1 bahwa kecerdasan emosional akan lebih efektif berpengaruh tidak langsung terhadap kinerja perawat melalui kepuasan kerja. Lain halnya dengan variabel kompetensi kerja dan komitmen organisasi lebih efektif berpengaruh langsung terhadap kinerja perawat. Adapun variabel kepuasan kerja hanya dapat memediasi variabel kecerdasan emosional sehingga model ini bersifat partial mediating.

Tabel 1. Pengaruh Langsung dan Tidak Langsung Kecerdasan Emosional, Kompetensi Kerja, Komitmen Organisasi dan Kepuasan Kerja serta Kinerja Perawat

\begin{tabular}{llll}
\hline \multicolumn{1}{c}{ Variabel } & \multicolumn{1}{c}{$\begin{array}{c}\text { Pengaruh Langsung } \\
\text { Terhadap Kinerja Perawat } \\
(\boldsymbol{\%})\end{array}$} & $\begin{array}{c}\text { Pengaruh Tidak Langsung Terhadap } \\
\text { Kinerja Perawat Melalui Kepuasan } \\
\text { Kerja }\end{array}$ & Ket \\
\hline Kecerdasan Emosional & $(0.50)^{2}=0.25$ & $0.69 \times 0.58=0.40$ & $\mathrm{~L}<\mathrm{TL}$ \\
Kompetensi Kerja & $(0.65)^{2}=0.4225$ & $0.57 \times 0.58=0.3306$ & $\mathrm{~L}>\mathrm{TL}$ \\
Komitmen Organisasi & $(0.74)^{2}=0.5476$ & $0.54 \times 0.58=0.3132$ & $\mathrm{~L}>\mathrm{TL}$ \\
Kepuasan Kerja & $(0.58)^{2}=0.3364$ & - & - \\
\hline
\end{tabular}

Pengaruh kecerdasan emosional, kompetensi, komitmen organisasi secara bersama-sama terhadap kepuasan kerja

$\mathrm{R} 1=0.56$

Pengaruh variabel luar terhadap KEPUASAN KERJA

$\zeta 1=0.44$

Pengaruh kecerdasan emosional, kompetensi, komitmen organisasi, kepuasan kerja secara bersamasama terhadap kinerja perawat

r2 $=0.84$

pengaruh variabel luar terhadap kinerja perawat

Sumber: Hasil Pengolahan Data (2016)

Keterangan $: T L=$ Tidak Langsung; $L=$ Langsung 


\section{Temuan Hasil Penelitian}

Berdasarkan hasil penelitian di atas, maka temuan dari penelitian ini adalah Kinerja Perawat Puskesmas di DKI Jakarta akan meningkat terutama pada Inisiatif Kerja (Y6) jika Perawat Puskesmas di DKI Jakarta memiliki Kepuasan Kerja yang tinggi terutama dalam hubungan antar staf (KK13), dimana Kepuasan Kerja akan meningkat jika perawat Puskesmas mempunyai Kecerdasan Emosional terutama dalam Kemampuan mengatur atau mengarahkan diri (KE9), memiliki Kompetensi Kerja yang tinggi khususnya dengan Tingkat kepercayaan dalam bekerja (KOM5), serta kuatnya Komitmen Organisasi terutama dalam aspek Tingkat kepedulian pegawai untuk ikut menyelesaikan permasalahan organisasi (KO3).

Selain hal tersebut di atas, penelitian ini juga menemukan bahwa ternyata variabel Kepuasan Kerja tidak memediasi variabel Kompetensi Kerja dan Komitmen Organisasi dalam mempengaruhi Kinerja perawat Puskesmas di DKI Jakarta. Dengan demikian variabel Kompetensi Kerja dan Komitmen Organisasi menunjukkan perannya secara langsung dalam meningkatkan Kinerja perawat Puskesmas di DKI Jakarta. Perawat yang memiliki Kompetensi Kerja yang mumpuni dan mempunyai Komitmen Organisasi yang tinggi akan memberikan pengaruh yang positif dan signifikan terhadap peningkatan Kinerja perawat secara keseluruhan terhadap organisasi Puskesmas di DKI Jakarta. Untuk variabel Kecerdasan Emosional ternyata dalam perannya untuk meningkatkan Kinerja perawat Puskesmas di DKI Jakarta agar lebih memberikan arti positif dan signifikan, maka perlu dimediasi oleh variabel Kepuasan Kerja.
Dari hasil penelitian ditemukan beberapa hal penting sebagai berikut:

1. Kecerdasan Emosional dengan dimensi yang paling merefleksikan adalah Kemampuan Intrapersonal (X1) dan indikator Kemampuan mengatur atau mengarahkan diri (KE9) terbukti berpengaruh positif dan signifikan secara parsial terhadap Kepuasan Kerja dengan dimensi yang paling merefleksikan adalah Hubungan Sosial (Y3) dan nilai Koefisien Regresi sebesar 0.69 serta t hitung $8.78>\mathrm{t}$ tabel 1.96 .

2. Kompetensi Kerja dengan dimensi yang paling merefleksikan adalah Kepercayaan (X6) dan indikator Tingkat kepercayaan dalam bekerja (KOM5) terbukti berpengaruh positif dan signifikan secara parsial terhadap Kepuasan Kerja dengan dimensi yang paling merefleksikan adalah Hubungan Sosial (Y3) dan nilai Koefisien Regresi sebesar 0.57 serta $t$ hitung $7.45>\mathrm{t}$ tabel 1.96.

3. Komitmen Organisasi dengan dimensi yang paling merefleksikan adalah Keterlibatan (X8) dan indikator Tingkat kepedulian pegawai untuk ikut menyelesaikan permasalahan organisasi (KO3) terbukti berpengaruh positif dan signifikan secara parsial terhadap Kepuasan Kerja dengan dimensi yang paling merefleksikan adalah Hubungan Sosial (Y3) dan nilai Koefisien Regresi sebesar 0.54 serta $t$ hitung $7.87>\mathrm{t}$ tabel 1.96.

4. Kecerdasan Emosional, Kompetensi Kerja dan Komitmen Organisasi terbukti secara bersama-sama berpengaruh positif dan signifikan terhadap Kepuasan Kerja, dengan nilai $\mathrm{F}$ hitung 8,45 > F Tabel 2,64, dengan kontribusi sebesar 56\%. Kecerdasan Emosional dengan dimensi yang paling 
merefleksikan adalah Kemampuan Intrapersonal (X1) merupakan variabel yang paling dominan berpengaruh terhadap Kepuasan Kerja dengan dimensi yang paling merefleksikan adalah Hubungan Sosial (Y3).

5. Kecerdasan Emosional dengan dimensi yang paling merefleksikan adalah Kemampuan Intrapersonal (X1) dan indikator Kemampuan mengatur atau mengarahkan diri (KE9) terbukti berpengaruh positif dan signifikan secara parsial terhadap Kinerja perawat dengan dimensi yang paling merefleksikan adalah Inisiatif Kerja (Y6) dan nilai Koefisien Regresi sebesar 0.50 serta $t$ hitung $9.85>\mathrm{t}$ tabel 1.96 .

6. Kompetensi Kerja dengan dimensi yang paling merefleksikan adalah Kepercayaan (X6) dan indikator Tingkat kepercayaan dalam bekerja (KOM5) terbukti berpengaruh positif dan signifikan secara parsial terhadap Kinerja perawat dengan dimensi yang paling merefleksikan adalah Inisiatif Kerja (Y6) dan nilai Koefisien Regresi sebesar 0.65 serta $t$ hitung $8.32>\mathrm{t}$ tabel 1.96.

7. Komitmen Organisasi dengan dimensi yang paling merefleksikan adalah Keterlibatan (X8) dan indikator Tingkat kepedulian pegawai untuk ikut menyelesaikan permasalahan organisasi (KO3) terbukti berpengaruh positif dan signifikan secara parsial terhadap Kinerja perawat dengan dimensi yang paling merefleksikan adalah Inisiatif Kerja (Y6) dan nilai Koefisien Regresi sebesar 0.74 serta thitung $8.44>$ t tabel 1.96.

8. Kepuasan Kerja dengan dimensi yang paling merefleksikan adalah Hubungan Sosial (Y3) dan indikator Hubungan antar staf (KK13) terbukti berpengaruh positif dan signifikan secara parsial terhadap Kinerja perawat dengan dimensi yang paling merefleksikan adalah Inisiatif Kerja (Y6) dan nilai Koefisien Regresi sebesar 0.58 serta $\mathrm{t}$ hitung $7.96>\mathrm{t}$ tabel 1.96 .

9. Kecerdasan Emosional, Kompetensi Kerja, Komitmen Organisasi dan Kepuasan Kerja terbukti secara bersama-sama berpengaruh positif dan signifikan terhadap Kinerja perawat dengan $\mathrm{F}$ hitung $8.05>\mathrm{F}$ tabel 3.03 dengan kontribusi sebesar $84 \%$. Komitmen Organisasi dengan dimensi yang paling merefleksikan adalah Keterlibatan (X8) merupakan variabel yang paling dominan berpengaruh terhadap Kinerja perawat dengan dimensi yang paling merefleksikan adalah Inisiatif Kerja (Y6).

Variabel Kompetensi Kerja dan Komitmen Organisasi menunjukkan perannya secara langsung (partial mediating) dalam meningkatkan Kinerja perawat Puskesmas di DKI Jakarta.

\section{Implikasi Manajerial}

1. Berdasarkan temuan hasil penelitian untuk dapat meningkatkan Kepuasan Kerja perawat Puskesmas di DKI Jakarta, maka ketiga variabel Kecerdasan Emosional, Kompetensi Kerja dan Komitmen Organisasi dapat dipakai atau digunakan. Namun secara parsial perhatian lebih difokuskan yang ditujukan pada variabel Kecerdasan Emosional dengan dimensi yang paling merefleksikan adalah Kemampuan Intrapersonal (X1) dalam mempengaruhi Kepuasan Kerja perawat maka fokus perhatian ditujukan pada dimensi ini.

2. Berdasarkan hasil penelitian untuk dapat meningkatkan Kinerja perawat 
perawat Puskesmas di DKI Jakarta maka keempat variabel Kecerdasan Emosional, Kompetensi Kerja, Komitmen Organisasi dan Kepuasan Kerja dapat dipakai atau digunakan. Namun secara parsial perhatian lebih fokus ditujukan pada variabel Komitmen Organisasi dengan dimensi yang paling merefleksikan adalah Keterlibatan (X8) maka fokus perhatian ditujukan pada dimensi ini.

3. Hasil penelitian juga menunjukkan bahwa variabel Kepuasan Kerja tidak memediasi variabel Kompetensi Kerja dan Komitmen Organisasi dalam mempengaruhi Kinerja perawat Puskesmas di DKI Jakarta. Dengan demikian variabel Kompetensi Kerja dan Komitmen Organisasi menunjukkan perannya secara langsung dalam meningkatkan Kinerja perawat Puskesmas di DKI Jakarta. Perawat yang memiliki Kompetensi Kerja yang mumpuni dan mempunyai Komitmen terhadap organisasi yang tinggi akan memberikan pengaruh yang positif dan signifikan terhadap peningkatan Kinerja perawat secara keseluruhan terhadap organisasi Puskesmas di DKI Jakarta. Dimensi yang paling merefleksikan untuk variabel Kinerja perawat adalah Inisiatif Kerja, yang merupakan salah satu kunci keberhasilan dalam melaksanakan pekerjaan untuk mendukung peningkatan Kinerja perawat secara komprehensif di dalam organisasi Puskesmas. Perawat harus memiliki Inisiatif Kerja yang tinggi, sehingga akan mendorong terhadap peningkatan Kinerja di dalam organisasi Puskesmas.

\section{Kesimpulan}

Berdasarkan implikasi manajerial terkait peningkatan Kinerja perawat Puskesmas di DKI Jakarta, ternyata variabel Kepuasan Kerja tidak memediasi variabel Kompetensi Kerja dan Komitmen Organisasi. Dengan demikian dalam hal peningkatan Kinerja perawat harus di titikberatkan pada pengembangan dan peningkatan Kompetensi Kerja perawat dan Komitmen perawat terhadap Organisasi Puskesmas. Dengan Kompetensi Kerja yang tinggi dan memiliki Komitmen Organisasi yang baik, seorang perawat dapat menjadi perawat yang profesional dan memiliki Inisiatif Kerja yang tinggi, sehingga akan meningkatkan Kinerja perawat Puskesmas di DKI Jakarta.

\section{Daftar Pustaka}

1. Sistem Kesehatan Nasional Tahun 2009

2. Undang-Undang Kesehatan No. 36 Thn 2009

3. Laporan Dinas Kesehatan Propinsi DKI Jakarta, 2016

4. Profil Kesehatan Kab/Kota Administratif Tahun 2011 - 2015, Jumlah Kunjungan Puskesmas Provinsi DKI Jakarta Tahun 2011 - 2015 